\title{
AFFORDABLE HOUSING AND THE FUTURE OF CITIES
}

\author{
Sasha Tsenkova
}

\section{Context and Rationale for the Book}

The shortage of affordable housing in cities is one of the most significant global challenges. It affects 1.6 billion people (one-third of urban population) and is a key priority for policy change identified by the United Nations in the New Urban Agenda (Tsenkova, 2016). Globally, cities and central governments have championed housing strategies and action plans, with a strong emphasis on effective partnerships to ensure housing efficiency in an effort to make cities livable and sustainable. In the context of the COVID-19 public health crisis, access to affordable and adequate housing has become extremely important, providing a refuge in the midst of rapid urban transformation and collapsing urban economies. The need for a resilient housing system, capable of responding to external shocks with the inherent ability to bounce back, will indeed define the success of cities in the future. Problems of housing affordability and accessibility have become more pressing during the pandemic. Cities during lockdowns have delivered a rapid response through rent freezes, tenant protection, provision of emergency shelters, conversion of underutilised hotels and offices into affordable housing and the building of more permanent solution using modular and prefabricated technologies. In many places, the crisis has triggered political commitments and action to address the supply challenge, providing a sustainable range of affordable housing solutions. In the wake of post-pandemic recovery, the unprecedented challenges to public health in cities have demonstrated the need to consider affordable housing as a critical part of social infrastructure that requires sustained investment and support to establish a resilient ecosystem of housing providers (Tsenkova, 2021).

This stands in sharp contrast to the long-term decline in social and affordable housing investment in many contexts since the late 1970s (Angel, 2000). While there is no common definition of social housing, the book recognises the contextual differences in the structure, policies and trajectories in different countries (van Bortel et al., 2019). We use the term 'social housing' to recognise these differences and important nuances in interpretation to as housing systems are path-dependent. In European countries with a large share of social housing, the sector operates like a 'social market' in direct competition with private renting. The institutional arrangements favour ownership by not-for-profit or private landlords, rents are based on cost recovery principles and allocation extends access to a more diverse income group. Europe, the Netherlands, Sweden, Denmark, Germany and Austria exemplify the characteristics of such unitary systems 


\section{Sasha Tsenkova}

(Kemeny, Kersloot and Thalmann, 2005). The United Kingdom and France have a strong legacy of public/council housing, which despite some residualisation, has seen a growing commitment to provision of social housing through mixed-income, mixed-tenure projects in the last decade (Bailey et al., 2006; Kearns et al., 2013). At the other end of the spectrum, in most countries, social housing has a residual role, and the small sector-less than $5 \%$ - operates as a safety net. Access is reserved for low-income households, allocation is rationed, rents are heavily subsidised and management is carried out by public institutions. The terminology in housing policy discourse refers to public housing as the dominant form of social housing, while more recent programmes will target affordable housing, usually in some form of mixed income. All post-socialist countries, after a dramatic privatisation of public housing in the 1990s, fall in this category, as well as Canada and the United States (Tsenkova, 2021).

Notwithstanding these path-dependent characteristics of social and affordable housing systems in different countries, housing policy reforms since the 1990s have moved away from bricks and mortar to demand-based subsidies and towards more market-oriented provision models (Sousa \& Quarter, 2003; Stephens, Burns \& Mackay, 2002). The growing dependence on private housing finance and the opening up of a previously sheltered systems of social housing provision have created a more entrepreneurial model with considerable changes regarding the role of social housing in cities, the way it is provided and for whom. While historically public housing played a significant role in shaping urban communities, in the era of neoliberal reforms, its future was challenged by declining investment, ageing infrastructure and design that was less conducive to social integration (Bacher, 1993; Oxley, 2000). Over time, the compositions of actors and agencies involved shifted drastically from public provision towards multi-actor/agency collaboration (Berry, 2014). Socially owned housing managed by nonprofit, private and community-based organisations in 'hybrid' forms replaced public housing to address the needs of targeted groups (i.e., the homeless, seniors, vulnerable households), but its growth remained limited despite the increasing affordability gap in many cities (Dalton, 2009; Fraser \& Kick, 2007).

In the aftermath of the 2008 global financial crisis, the cracks in the models of affordable housing delivery highlighted the vulnerability of the system. The crisis also provided an opportunity to reconsider the policy support and alignment of financial, fiscal and regulatory instruments to build resilience (Tsenkova, 2014). Given the devolution of government involvement in affordable housing, consensus emerged that an effective response requires a multi-sectoral approach, including all levels of government, the private for-profit and non-profit sectors, as well as local communities. This is perceived as the most effective way of producing affordable housing to meet growing local needs within limited resources and capacity (Scanlon, Whitehead \& Arrigoitia, 2014; van Bortel et al., 2019). The last decade has seen large cities across Europe and North America join their efforts with non-profit and private organisations to provide affordable rental housing in mixed-income, mixed-tenure projects. In some cases, the model had a strong legacy, and it was 'business as usual' in countries with unitary social housing systems. In other places, the shift triggered a range of experimental strategies to redevelop large-scale public housing complexes or to reinvent brownfield sites in cities into inclusive neighbourhoods emphasising social mix and integration (Tsenkova, 2019). Such solutions to the affordable housing challenge in cities demonstrated a viable alternative to address vulnerabilities in the housing market as well as make cities more inclusive and competitive.

This book focuses on these solutions and provides comparative perspectives on partnerships for mixed-income affordable housing as a model of neighbourhood revitalisation and city building. Focusing on the nexus of planning, design and policy, it explores good practices in 15 cities in Europe, Canada and USA using a strong conceptual approach and multidisciplinary 
methods of analysis. This richly illustrated collection of case studies includes contributions from 25 world-class scholars, architects, city leaders, planners and housing experts committed to innovative approaches to socially inclusive cities.

\section{Conceptual Approach}

The future of affordable housing requires a different approach to socially inclusive cities based on partnerships, people-centred design and innovative planning. The mixed-income model is globally recognised as the best practice in many cities in the UK, France, the Netherlands, Austria, Germany and the USA, where the provision of mixed-income housing in different forms is a normative requirement (Scanlon, Whitehead, \& Arrigoitia, 2014). The overall goal of mixed-income housing is to establish better quality of life and adequate living conditions for all residents. There is ample research conducted on the efforts, rationale and importance of mixed-income housing (Bailey et al., 2006; Livingston, Kearns, \& Bailey, 2013). However, the theoretical framework, conceptual clarity and empirical justification are underexamined. We have adopted a conceptual approach that focuses on place-based and people-based outcomes of mixed-income affordable housing delivered through partnerships (Tsenkova, 2014). The framework is applied to explore a variety of city-led strategies in seven European countries, USA and Canada by using original, multidisciplinary research methods of analysis. The nexus of housing policy, planning and design is a critical lens for these multi-scalar explorations at the level of cities, neighbourhoods and specific projects. The conceptual approach in the book brings a sustainability perspective to the exploration of partnership models by emphasising the need for equity and social inclusion through social mix and environmental sustainability of the built forms through design.

\section{Efficiency through Partnerships for Affordable Housing}

Recent housing reforms respond to the 'market failure' in affordable housing defined by Berry (2014) as lack of stable and consistent policies, absence of planning mechanisms that regulate affordable housing and a failure in governance to coordinate and strategise. On the policy side, a renewed commitment of governments, complemented with city-based strategies and municipal programmes, demonstrates a transformative change in the supply of affordable, adequate and secure rental housing (Kemeny, Kersloot, \& Thalmann, 2005; Tsenkova, 2019). National and city-led housing strategies provide municipalities with a significant opportunity to realign resources, land and infrastructure investments, as well as leverage the capacity of the housing industry and the not-for-profit providers to support partnerships in mixed-income, mixed-tenure projects (Moore \& Skaburski, 2004; Smith, 2002). This is the most efficient way of producing affordable housing to meet growing local needs, particularly in the context of inner-city neighbourhood rebuilding.

The theoretical framework for housing partnerships is based on collaborative planning, consensus-based decision-making, non-hierarchical structures and processes, synergistic interactions among partners and shared accountability for outcomes and results (see Bovaird, 2004; Brinkerhoff \& Brinkerhoff, 2011). Recent research profiles a model of public, private and nonprofit (PPNP) partnership that has evolved to deliver affordable rental housing, capitalising on the strengths of each sector. The public sector (federal, provincial, municipal) is effective in the mobilisation of much-needed resources, while the private sector (designers, developers, housing industry, construction companies) is efficient in managing the construction process by maximising economies of scale and tapping into technological innovation and marketing strategies. 


\section{Sasha Tsenkova}

Not-for-profit housing institutions are more efficient in managing and operating affordable rental housing due to the extensive knowledge of the people they service (Tsenkova, 2019). In large-scale developments, such synergies are important in the provision process (design, build, finance, operate) as insights from neighbourhoods in Montréal, London, Paris, Amsterdam, Vienna and New York demonstrate.

PPNP partnerships maximise such synergies through collaborative processes of jointly determined goals, decision-making, non-hierarchical institutional structures of the housing development process and shared accountability for outcomes and results. Public authorities employ various policy instruments to implement partnership projects through a wide range of innovations in public/private funding and planning instruments with varying capacities to address the affordability gap (Black, 2012). Municipalities often take a strategic leadership role, defining the share of affordable rental housing in mixed-income neighbourhoods, leveraging the value of public land and infrastructure investment, increasing densities and incorporating planning and design strategies to facilitate social mix and integration of projects in communities.

A variety of partnerships can be delineated on a continuum, depicting the transfer of liability and risk from the public to the private and non-profit sectors in key phases of the development process - plan, finance, design, build, operate, own/lease. The institutional landscape is quite diverse, and every stage represents a mix of private, public and non-profit agencies, depending on the scale of the development and specific local housing markets (Tsenkova, 2019). While there is no set of prescribed guidelines in different cities, some of the small-scale partnership projects will typically fall in the category 'design-build', where the private sector has a limited responsibility, often referred to public-private partnerships that build on efficiencies of scale and expertise. In the case of larger, block-size mixed-income developments, a more ambitious PPNP model of 'design-build-operate' evolves, where a full range of publicly financed housing agencies (private and not-for-profit) delivers affordable rental housing, often over a period of 25-50 years. These models sketched in broad strokes capture a complex reality with very fluid institutional arrangements. The PPNP partnerships have a strong involvement and leadership of non-profit organisations acting as socially responsible developers, mobilising public sector financial and fiscal support to ensure financial viability. Public sector involvement is typically limited to financing, transfer of land and the definition of key planning outcomes (housing typology, rent levels, access to neighbourhood amenities).

Municipal governments have a critical role in the provision of affordable rental housing (Carmona, Carmona \& Gallent, 2003; Whitehead, 2007). Some of the incentives and planning strategies to stimulate mixed-income, mixed-tenure housing projects include waiving development charges, selling municipal land at discounted rates, lowering property taxes, inclusionary zoning or start-up grants/loans. In addition, municipalities expedite the planning approval process and encourage private developers to join partnerships with city-owned or non-profit housing providers to build developments with varying degrees of affordable housing.

\section{Equity through Social Mix in Affordable Housing}

'Social mix' refers to the integration of people of different social standing or identity. The term is used in relation to affordable housing and sustainable neighbourhoods to describe an environment where housing offers diverse opportunities in terms of types, tenure, costs and design to respond to a diversity of needs (Galster, 2013). In many European countries, social mix through the planning process is a normative requirement, specifying targets of $20-25 \%$ affordable rental housing as a desirable tenure mix to bring a mix of people together by offering housing for a range of income levels in a single development or in neighbourhood (Scanlon, 
Whitehead \& Arrigoitia, 2014). The social mix approach aims at combating economic, social and ethnic segregation. It is justified on grounds of both economic efficiency-making society as a whole better-off by enhancing solidarity, labour productivity and community sustainability - and equity-improving the life-chances and social inclusion of disadvantaged groups (Bolt \& van Kempen, 2010).

Social mix in North America became prominent in the 1970s as a response to growing social inequalities and stigma attached to large subsidised housing developments (Kearns et al., 2013). This resulted in the revitalisation of public housing projects and their replacement with mixedincome developments to promote social mix. Neighbourhood planning initiatives include urban regeneration, with an emphasis on housing mix, inclusion of rental housing through zoning and density bonusing policies, provision of public land for affordable rental housing, encouragement of public/private partnerships and rent supplements to allow local residents to stay-in-place (Galster, 2013; Smith, 2002). The pursuit of social mix is innovative in many contexts where the share of social and affordable housing is small. Inclusionary zoning in Canadian and US cities is used to a limited extent to guide the planning and development of inclusive and equitable neighbourhoods. Due to the dynamic nature of social mix, there are multiple ways it can be implemented at various scales, but the practice can be challenging (Arthurson, 2010; Thurber, Bohmann \& Heflinger, 2018). Social mix can take place in a building, on a street, in a block or in a neighbourhood. Some of the best practices include making the difference between low-income and market housing non-existent, using common spaces to promote interaction between residents, and minimising the impacts of displacement during changes within existing communities.

\section{Environmental Sustainability through Design}

Affordable housing partnerships through PPNP collaboration in cities are used as a social planning strategy to address the shortage of affordable rental housing, foster social mix and regenerate brownfield sites (Katz, 2004). Notwithstanding the complexities of these collaborations, they provide critical opportunities to improve the built environment through coordinated investment in infrastructure, development of a variety of housing types, ownership opportunities (social and modest market rental housing and affordable homeownership) and investment in neighbourhood amenities, transit and retail (Ramzanpour \& Noutaghani, 2019). Such large-scale redevelopment projects bring brownfield city sites back to life, creating new attractive neighbourhoods inspired by sustainability plans, but present significant challenges (Bond, Sautkina \& Kearns, 2011). While residential intensification and planning strategies enhance the quality of built form and encourage higher-density mixed-use developments, the provision of quality affordable housing is essential to maintain diversity of residents and social mix (Karakusevic \& Batchelor, 2018). The creation of mixed-income, mixed-tenure neighbourhoods depends on the plans, but also on the successful PPNP partnerships for plan implementation.

In many contexts, different systems promote energy-efficient design, smart communities and the use of strategies to enhance environmental sustainability. Partnership projects for mixedincome integrated housing development often comply with, or even lead in terms of performance related to smart location and access, street pattern and design, and the use of green technology and building techniques. The green stamp of approval, while rigorous in terms of smart, green and well-designed neighbourhoods, does not really emphasise housing affordability, so these examples are pushing the envelope in terms of social integration by design (Tsenkova, 2014). The overall goal of mixed-income housing is to establish better quality of life and adequate living conditions for all residents (Bailey et al., 2006). To understand successful mixed-income affordable housing, we have adopted a conceptual framework that focuses on 


\section{Sasha Tsenkova}

place-based and people-based outcomes. The success of building such strong communities involves synergies of physical, social and environmental measures.

The built environment has an important impact on place-based outcomes, defining neighbourhood qualities, types of housing, density of urban form, amenities and access to common spaces and services (parks, schools, transit). While such qualities of the built environment have been a significant focus of housing policies, the evidence of how design impacts mixed-income housing to achieve good people-based outcomes is less conclusive (Bond, Soutkina \& Kearns, 2011). Within the planning and design profession, place-based outcomes are often easier to influence, but the social impact on residents remains limited. Research recognises that peoplerelated outcomes are about access to adequate housing, but also about social development, wellbeing and opportunities for civic participation (Joseph, Chaskin \& Webber, 2007). The case studies in this book deliver a strong message that excellence by design is critical for the quality of affordable housing and the well-being of its residents.

\section{Planning-Design-Policy Nexus}

A final concept in the book is related to the planning-design-policy nexus (Legacy, Davidson \& Liu, 2016). Nexus thinking transcends traditional policy and decision-making silos and develops approaches that build synergies across these sectors (Sharmina et al., 2016). Partnerships for affordable housing in cities are indeed very diverse multi-sectoral collaborations that leverage real estate market pressures to promote affordability goals and social mix. Cities often take the lead in managing the planning-design-policy nexus as neighbourhood rebuilding takes decades and shifting the responsibility to private developers might not work, particularly in the context of gentrification and displacement of lower-income residents. Partnerships need robust and sustained financial support, alignment of planning policies and institutional commitment to increase the supply of affordable rental housing. Such complexity by design makes statements on 'what works' and 'what does not' challenging and illustrates the interdependent nature of resilience at the nexus, raising the fundamental questions how policy might enable systemic resilience. Each city will need to develop its own successful model, based on resilience of the planning-design-policy nexus for affordable housing to respond to growing affordability pressures while emphasising diversity and social mix.

\section{Main Themes in the Book}

Building on the success of a three-year collaborative research project, the Cities and Affordable Housing book brings forward evidence-based research on what works and what does not work and how to move forward. Established scholars, planners and housing experts have collaborated to explore planning, policy and design innovation in Calgary, Edmonton, Vancouver, Toronto, Montréal, New York, Boston, Washington DC, Cleveland, Seattle, Paris, London, Amsterdam, Copenhagen and Vienna. The narratives are multidisciplinary, unique and richly illustrated. The chapters are organised around five themes explored through case studies, comparative research, critical reflections on innovative models and practices and evidence-based design work. The following sections highlight important issues addressed in each thematic cluster.

1. Cities and Affordable Housing. How to implement new planning and design strategies for mixed-income affordable housing in cities? How to mobilise the network of public, private and non-profit organisations, as well as the local communities, to support reforms for affordable housing partnerships? The development of partnerships requires funding, expertise, capacity and effective management of the interdependence between organisations 
to deliver affordable homes (Tsenkova, 2019) and adapt to risks (Gilbert, 2016). The contributions in this section include best practices of city-led strategies that impact place-based outcomes - the mix of housing types, access to land and integration in the neighbourhood (Thurber, Bohmann \& Heflinger, 2018).

La Ferrière explores the implementation of different initiatives to grow social and community housing in Montréal, and the success of an inclusionary strategy to support mixed-income neighbourhoods. Bond reviews planning tools to foster mixed-income communities and to provide a range of new affordable homes that meet the needs of those who live and work in Vancouver. Woodgate, Goldstein and Noble explore the affordable housing transformation in Calgary, with a strong emphasis on partnerships and collaboration to deliver tangible results. Anderson-Baron and Kjenner emphasise the role of the City of Edmonton as an enabler of affordable housing for over six decades, leveraging the capacity of diverse partners, using proactive policy development, planning tools and a unique regulatory approach to increase access to adequate and affordable housing choices. Gadon's contribution, featuring the experience of Toronto, focuses on leveraging public land for affordable housing development through a range of public/ private/non-profit housing partnerships.

2. Mixed-Income Housing and Community Building. City-led strategies for mixedincome housing employ various policy instruments to implement transformation (Ramzanpour \& Nourtaghani, 2019). Evidence documents that mixed-income development counteracts the negative effects of social isolation and concentration of inner-city poverty and promotes increased mobility among low-income residents (Joseph, Chaskin \& Webber, 2007). Building on the political economy of place argument, the chapters address the successes and failures of policy instruments-regulation, resources, institutional capacity and network building - to ensure more efficient and effective implementation of mixed-income housing models (Arthurson, 2010; Atkinson \& Kintrea, 2001).

Shomon Shamsuddin presents a conceptual framework for understanding mixed-income housing and illustrates how variations manifest in neighbourhoods. Hirsch, Joseph and Khare explore mixed-income public housing transformation in San Francisco and Washington DC. They examine the tensions and trade-offs of transforming public housing in these city-led initiatives and identify key implications for success in future equity-oriented mixed-income efforts. Dauphin and Schwoerer from Paris Habitat- the largest social housing provider in Paris- present an award-winning design of a new mixed-income, mixedtenure neighbourhood. The model capitalises on a robust system of support in the French social housing system while illustrating opportunities for sustainable adaptive reuse of heritage resources. Vincent Tong discusses challenges and opportunities in the redevelopment of Regent Park — the largest public housing in Toronto- set to deliver 4,805 rental replacement units on 87 hectares of land. After 12 years of revitalisation through mixed-income opportunities, the results illustrate important lessons for cities developing inclusive social housing communities.

3. Affordable Housing Partnerships in Practice. How to implement new partnership models for affordable housing to increase its supply? What are the models of these collaborations? What is the strategic role of municipalities? While there is a common mandate to provide housing that is affordable, the definitions and criteria for allocation and eligibility, governance and management policies, and typologies of housing forms vary widely (Joseph \& Khare, 2020). Socially owned housing managed by non-profit, private and community-based organisations in 'hybrid' forms in cities is a viable model of 
mixed-income affordable housing, but is not necessarily resilient in times of fiscal austerity (Scanlon, Whitehead \& Arrigoitia, 2014). The contributions in this section highlight patterns of diversity in cities and offer practical insights into the nexus of policy, planning and design affecting mixed-income housing.

Schwartz and Tsenkova review the mixed-income housing supported through a variety of housing plans in New York City. Such interventions build upon a strong political commitment to affordable rental housing since the 1980s, supportive policy environment and robust institutional partnerships with non-profits and private sector providers. Kath Scanlon explores how London deals with its growing affordable housing challenge through partnerships. New affordable housing is supplied by housing associations or by for-profit developers, who are required to build affordable homes as a condition of planning permission. Tsenkova's chapter documents patterns of resilience of social housing systems in Vienna, Amsterdam and Copenhagen. The research indicates that resilience is attributed to the robustness and resourcefulness of social housing institutions, but also to sustained and more coherent policy intervention that supports partnerships and neighbourhood rebuilding through social mix.

4. Design Innovation for Affordable Housing. How to support social mix and community building through better planning and design of affordable housing projects? The built form and spatial patterns of affordable housing use planning and design strategies to facilitate social mix and integration in communities (Ramzanpour \& Nourtaghani, 2019). What design strategies ensure that affordable is well integrated in terms of design, built form and public spaces? The contributions focus on design innovation to support people-based outcomes - healthy and sustainable housing-but also on opportunities for community integration, diversity and social inclusion.

Friedman advances the concept of flexible design in affordable housing, its design principles and application in the marketplace. Good-quality design in affordable and social housing is a critical component for a successful development. Avenier and Tsenkova illustrate innovative design strategies to improve the quality, functionality, asset value and acceptance of affordable housing using award-winning projects from Paris. In Europe, a new generation of architectural practices is transforming social housing across cities. Karakusevic explores how design changes the housing estates in Rotterdam and contributes to social mixing of generations, languages and cultures in Vienna. The case studies in London explore the integration of high-quality council housing in city's communities. Atteveld and Liesker illustrate how social housing projects in Amsterdam and Haarlem respond to the needs of residents through a variety of design strategies.

5. Policy Design for Affordable Housing. How to design policy to develop partnerships for affordable rental housing: rethinking the role of regulation, finance and resources to deliver results? Public authorities employ various policy instruments (fiscal, financial, regulatory) to implement urban transformation (Gilbert, 2016; Tsenkova, 2021). In an era of fiscal austerity, public investment in social housing has declined. In its place has come a wide range of innovations in public/private approaches to funding private rental and nonprofit housing, complemented with planning instruments with varying capacities to address the affordability gap (van Bortel et al., 2019). What are the shifts in the availability of demand- and supply-support for affordable housing and what experiences can be effectively transferred to other institutional environments? What is the critical role of private rental housing for socially inclusive cities and neighbourhoods? 
Haffner explores the pathways of Dutch and German housing policies that have resulted in different models of affordable rental housing. While the Netherlands has the largest social rental sector in the Western world, Germany has produced one of the largest private rental sectors in Europe where some suppliers are temporarily subsidised. Even though the systems of social renting are different, both countries have moved to locally controlled housing policy. David Hulchanski reviews the private rental housing in Montreal, Toronto, Calgary and Vancouver and its prospects to provide adequate and affordable housing. The arguments illustrate the importance of path-dependent housing policies and their potential contribution to a more inclusive and responsive housing system. Severson and Vos focus on an important policy lens for social and affordable housing that centres on social sustainability. They develop a framework linked to equity, inclusion, security and resiliency and operationalise it for housing providers so that they can manage the process in a coherent way.

\section{Concluding Comments}

The contributions in Cities and Affordable Housing address issues of fundamental importance to the future of cities. They provide a synthesis of academic knowledge and innovative planning and design practice on the themes of affordable housing partnerships for mixedincome, socially inclusive neighbourhoods as a model to rebuild cities. The book is the result of a three-year collaborative research project at the University of Calgary. Launched in 2018, the Affordable Housing Research Initiative aims to broker new knowledge, foster partnerships with industry and communities and advocate for action. It has resulted in two international conferences, public events and design exhibitions that explore strategies to create mixed-income affordable housing in compact, connected urban development. Global in scope, it has delivered rigorous research results available through a knowledge hub as a resource for students, planners, architects, developers, community activists and politicians, widely available to everyone (https://sapl.ucalgary.ca/labs/cities/housing-futures). This first action-based network received Canada Mortgage and Housing Corporation President's Award for Best Housing Research in 2019, recognising its innovative approach and the leadership of Dr Tsenkova (Figure 1.1).

Access to affordable housing in cities is of paramount importance in the context of COVID-19 pandemic, underscoring its significance for public health and urban resilience. The thematic emphasis on housing policy, urban planning and design contributes to multidisciplinary, systematic comparative perspective on the future of affordable housing that will benefit academics and practitioners. The results presented in this edited volume go a long way in disseminating evidence-based work of housing researchers, designers and policy-makers of fundamental importance for the social and economic well-being of urban residents. The book empowers practitioners, planners and community leaders through compelling narratives, critical reflections on good practices, design strategies and evidence-based approaches to affordable housing. Such call for action builds capacity for change and mobilises support for more equitable, inclusive and competitive cities.

\section{Acknowledgements}

The financial support from the Social Sciences and Humanities Research Foundation of Canada for this research is acknowledged. 

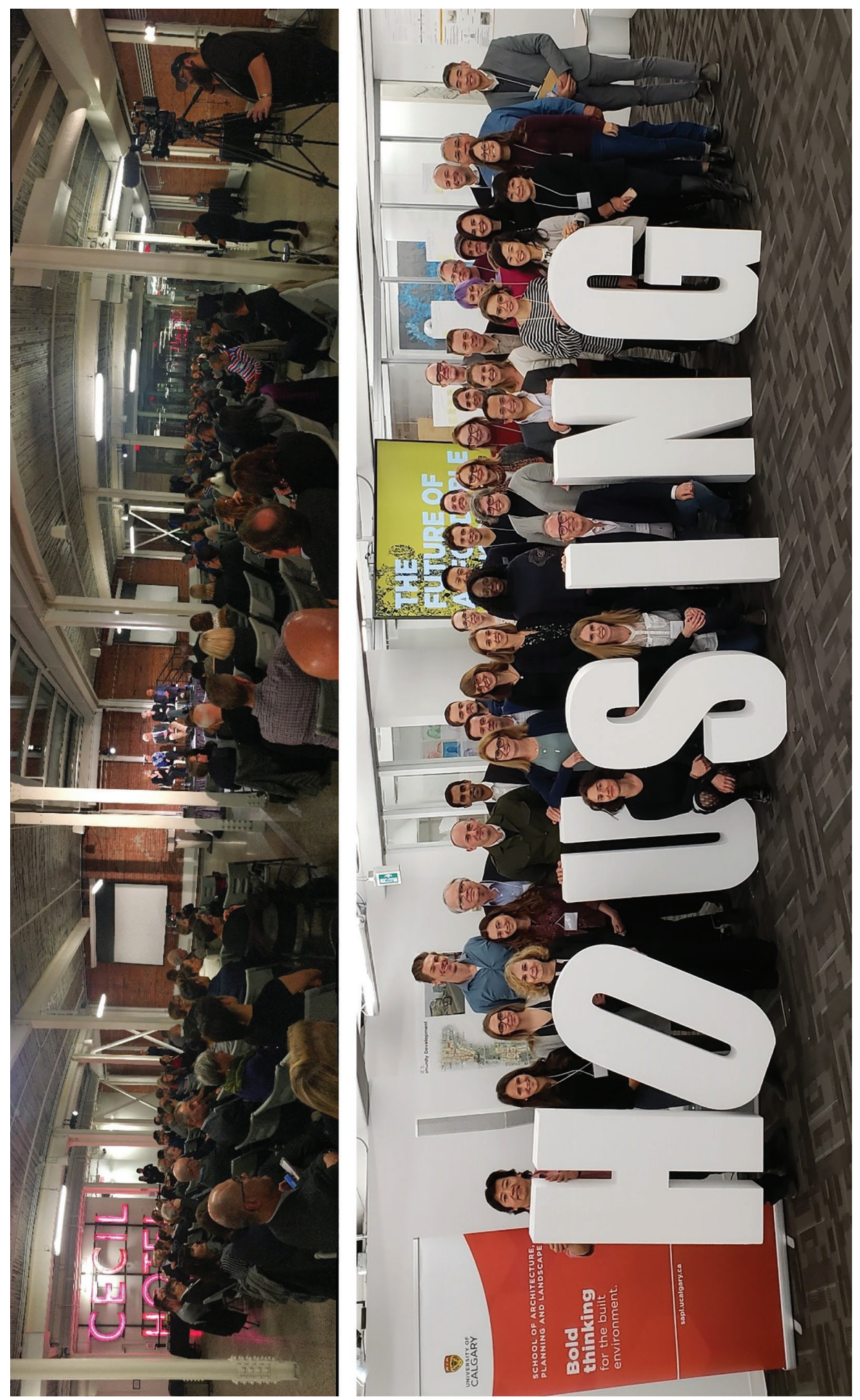

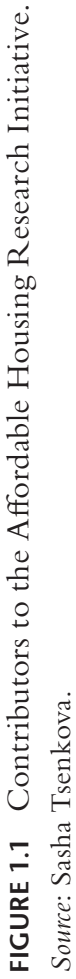




\section{References}

Angel, S. (2000). Housing Policy Matters - A Global Analysis. New York: Oxford University Press.

Arthurson, K. (2010). Questioning the Rhetoric of Social Mix as a Tool for Planning Social Inclusion. Urban Policy and Research, 28(2), 225-231.

Atkinson, R., \& Kintrea, K. (2001). Disentangling Area Effects: Evidence from Deprived and Nondeprived Neighbourhoods. Urban Studies, 38(12), 2277-2298.

Bacher, J. C. (1993). Keeping to the Marketplace: The Evolution of Canadian Housing Policy. Montréal: McGillQueen's University Press.

Bailey, N., Haworth, A., Manzi, T., Paranagamage, P., \& Roberts, M. (2006). Creating and Sustaining Mixed Income Communities: A Good Practice Guide. Coventry: Chartered Institute of Housing and Joseph Rowntree Foundation. Retrieved March 6, 2019, from www.jrf.org.uk/sites/default/files/jrf/ migrated/files/9781905018314.pdf

Berry, M. (2014). Neoliberalism and the City: Or the Failure of Market Fundamentalism. Housing, Theory and Society, 31(1), 1-18.

Black, J. (2012). The Financing \& Economics of Affordable Housing Development: Incentives and Disincentives to Private-Sector Participation. Toronto: Cities Centre, University of Toronto.

Bolt, G., Phillips, D., \& Van Kempen, R. (2010). Housing Policy, (De)segregation and Social Mixing: An International Perspective. Housing Studies, 25(2), 129-135.

Bond, L., Sautkina, E., \& Kearns, A. (2011). Mixed Messages about Mixed-Tenure: Do Reviews Tell the Real Story? Housing Studies, 26(1), 69-94.

Bovaird, T. (2004). Public-Private Partnerships: From Contested Concepts to Prevalent Practice. International Review of Administrative Sciences, 70(2), 199-215.

Brinkerhoff, D., \& Brinkerhoff, J. (2011). Public-Private Partnerships: Perspectives on Purposes, Publicness, and Good Governance. Public Administration and Development, 31(1), 2-14.

Carmona, M., Carmona, S., \& Gallent, N. (2003). Delivering New Homes: Processes, Planners, and Providers. London: Routledge.

Dalton, T. (2009). Housing Policy Retrenchment: Australia and Canada Compared. Urban Studies, 46(1), 63-91.

Fraser, J. C., \& Kick, E. L. (2007). The Role of Public, Private, Non-Profit and Community Sectors in Shaping Mixed-Income Housing Outcomes. Urban Studies, 44, 2357-2377.

Galster, G. C. (2013). Neighborhood Social Mix: Theory, Evidence, and Implications for Policy and Planning. In Carmon, N., \& Fainstein, S. S. (eds), Policy, Planning, and People: Promoting Justice in Urban Development. Philadelphia: University of Pennsylvania Press, 308-336.

Gilbert, A. (2016). Rental Housing: The International Experience. Habitat International, 54(3), 173-181.

Joseph, M., Chaskin, R., \& Webber, H. (2007). The Theoretical Basis for Addressing Poverty through Mixed-Income Development. Urban Affairs Review, 42(3), 369-409.

Joseph, M., \& Khare, E. (eds). (2020). What Works to Promote Inclusive, Equitable Mixed-Income Communities. Cleveland: National Institute for Mixed Income Communities.

Karakusevic, P., \& Batchelor, A. (2018). Social Housing: Definitions and Design Exemplars. London: RIBA Publishing.

Katz, B. (2004). Neighborhoods of Choice and Connection: The Evolution of American Neighborhood Policy and What It Means for the United Kingdom. The Brookings Institution. Retrieved March 8, 2019, from www.brookings.edu/wp-content/uploads/2016/06/20040713_katz.pdf

Kearns, A., McKee, M., Sautkina, E., Weeks, G., \& Bond, L. (2013). Mixed-Tenure Orthodoxy: Practitioner Reflections on Policy Effects. Cityscape, 15(2), 47-67.

Kemeny, J., Kersloot, J., \& Thalmann, P. (2005). Non-profit Housing Influencing, Leading, and Dominating the Unitary Rental Market: Three Case Studies. Housing Studies, 20(6), 855-872.

Legacy, C., Davison, G., \& Liu, E. (2016). Delivering Social Housing: Examining the Nexus between Social Housing and Democratic Planning. Housing, Theory and Society, 33(3), 324-341.

Livingston, M., Kearns, A., \& Bailey, N. (2013). Delivering Mixed Communities: The Relationship between Housing Tenure Mix and Social Mix in England's Neighbourhoods. Housing Studies, 28(7), 1056-1080.

Moore, E., \& Skaburski, A. (2004). Canada’s Increasing Housing Affordability Burdens. Housing Studies, 19(3), 395-413. 
Oxley, M. (2000). The Future of Social Housing Learning from Europe. London: Institution for Public Policy Research.

Ramzanpour, M., \& Nourtaghani, A. (2019). Impact of Four Physical Design Factors on Mixed-Income Housing. Journal of Architectural Engineering, 25(1), 1-8.

Scanlon, K., Whitehead, C., \& Arrigoitia, M. (eds). (2014). Social Housing in Europe. Oxford: Wiley-Blackwell.

Sharmina, M., Hoolohan, C., Bows-Larkin, A., Burgess, P., Colwill, J., Gilbert, P., Howard, D., Knox, J., \& Anderson, K. (2016). A Nexus Perspective on Competing Land Demands: Wider Lessons from a UK Policy Case Study. Environmental Science \& Policy, 59, 74-84.

Smith, A. (2002). Mixed-Income Housing Developments: Promise and Reality. Cambridge, MA: Joint Center for Housing Studies of Harvard University and Neighborhood Reinvestment Corporation.

Sousa, J., \& Quarter, J. (2003). The Convergence of Nonequity Housing Models in Canada: Changes to Housing Policy Since 1990. Housing Policy Debate, 14(4), 591-620.

Stephens, M., Burns, N., \& Mackay, L. (2002). Social Market or Safety Net? British Social Rented Housing in a European Context. Bristol: The Policy Press \& The Joseph Rowntree Foundation.

Thurber, A., Bohmann, C., \& Heflinger, C. (2018). Spatially Integrated and Socially Segregated: The Effects of Mixed-Income Neighbourhoods on Social Well-Being. Urban Studies, 55(9), 1859-1874.

Tsenkova, S. (2014). A Tale of Two Cities: Resilience of Social Housing in Vienna and Amsterdam. In Amann, W., Pernsteiner, H., and Struber, Ch. (eds)., Wohnbau in Österreich in Europäischer Perspective. Vienna: Manz Verlag and Universitatsbuchhandlung, 95-105.

Tsenkova, S. (2016). Sustainable Housing \& Livable Cities: The New Urban Agenda. Urban Research \& Practice, 9(3), 322-326.

Tsenkova, S. (2019). Partnerships: Creating Affordable Housing Opportunities in Canada. In Forster, W., \& Menking, W. (eds)., The Vienna Model 2: Housing for the City of the 21st century. Berlin: Jovis, 120-137.

Tsenkova, S. (ed.) (2021). Transforming Social Housing: International Perspectives. Abingdon: Routledge.

van Bortel, G., Gruis, V., Nieuwenhuijzen, J., \& Pluijmers, B. (eds). (2019). Affordable Housing Governance and Finance: Innovations, Partnerships and Comparative Perspectives. Abingdon: Routledge.

Whitehead, C. (2007). Planning Policies and Affordable Housing: England as a Successful Case Study? Housing Studies, 22(1), 25-44. 